\title{
Gambaran Klinis Penderita Penyakit Ginjal Kronik yang Menjalani Hemodialisis di RSUP Dr. M. Djamil Padang
}

\author{
Sitifa Aisara ${ }^{1}$, Syaiful Azmi ${ }^{2}$, Mefri Yanni $^{3}$
}

\begin{abstract}
Abstrak
Gambaran klinis Penyakit Ginjal Kronik (PGK) terlihat nyata bila ureum darah lebih dari $200 \mathrm{mg} / \mathrm{dl}$. Uremia menyebabkan gangguan fungsi hampir semua sistem organ seperti; gangguan cairan dan elektrolit, metabolikendokrin, neuromuskular, kardiovaskular dan paru, kulit, gastrointestinal, hematologi serta imunologi. Hemodialisis merupakan suatu usaha untuk mengurangi gejala uremia tersebut, sehingga gambaran klinis pasien juga dapat membaik. Tujuan penelitian ini adalah untuk mengetahui gambaran klinis penderita PGK yang menjalani hemodialisis di RSUP Dr. M. Djamil Padang. Jenis penelitian ini adalah deskriptif observasional. Sampel mencakup semua pasien PGK yang menjalani hemodialisis di RSUP Dr. M. Djamil Padang tahun 2015 yang memenuhi kriteria inklusi, sehingga didapatkan sebanyak 104 sampel. Jenis data adalah data sekunder yang diperoleh dari rekam medik. Hasil penelitian menunjukkan kebanyakan pasien adalah kelompok usia 40-60 tahun sebanyak $62,5 \%$ dan sebagian besar jenis kelamin pria sebanyak 59 pasien (56,7\%). Gambaran klinis paling banyak berupa keadaan gizi sedang 94,2\%, diikuti dengan kadar $\mathrm{Hb} 7-10 \mathrm{~g} / \mathrm{dl} 68,3 \%$, konjungtiva anemia $62,5 \%$, edema perifer $53,8 \%$, hipertensi derajat $132,7 \%$, lemah, letih, lesu sebanyak $30,8 \%$, dan mual $12,5 \%$. Simpulan penelitian ini adalah gambaran klinis penderita PGK yang menjalani hemodialisis di RSUP Dr. M. Djamil Padang terbanyak yaitu anemia hipertensi derajat satu, keadaan gizi sedang, konjungtiva anemia, dan edema perifer.
\end{abstract}

Kata kunci: penyakit ginjal kronik, hemodialisis, gambaran klinis

\section{Abstract}

Clinical features of Cronic Kidney Disease (CKD) will appear if urea blood levels is more than $200 \mathrm{mg} / \mathrm{dl}$. Uremia can cause malfunctioning of all organ systems, such as; disorder of fluid and electrolyte balance, endocrinemetabolic, neuromuscular, cardiovascular and lung, skin, gastrointestinal, hematology and immunology systems. The objective of this study was to determine the clinical features of patients with CKD that undergoing hemodialysis at RSUP Dr. M. Djamil Padang. This was a descriptive observational method based on secondary data obtained from medical records. Samples included all patients with CKD underwent hemodialysis at RSUP Dr. M. Djamil Padang in 2015 who were fulfilled inclusion criteria, with total 104 samples. Data were analyzed by using univariate analysis. The study showed that patients with CKD were mostly at ranged 40 to 60 years (62.5\%) and predominantly men (59 patients, 56.7\%). The most clinical features of the patient were moderate nutritional status (94.2\%), with $\mathrm{Hb}$ concentration 7-10g/dl (68.3\%), conjunctival anemia (62.5\%), peripheral edema (53.8\%), stage 1 hypertension (32.7\%), weakness and tired (30.8\%), and nausea (12,7\%). The conclusion is the most common clinical features of the patients with CKD undergoing hemodialysis at RSUP Dr. M. Djamil Padang were anemia, with first stage hypertension, moderate nutritional status and peripheral edema.

Keywords: chronic kidney disease, hemodialysis, clinical features

Affiliasi penulis: 1. Prodi Pendidikan Dokter Fakultas Kedokteran Universitas Andalas Padang (FK Unand), 2. Bagian Penyakit Dalam FK Unand/RSUP dr. M Djamil Padang, 3. Bagian Jantung dan Pembuluh Darah FK Unand/RSUP dr. M Djamil Padang
Korespondensi: Sitifa Aisara, Email: sitifa.aisara@gmail.com Telp:081374648666. 


\section{PENDAHULUAN}

Penyakit Ginjal Kronik (PGK) adalah suatu gangguan pada ginjal ditandai dengan abnormalitas struktur ataupun fungsi ginjal yang berlangsung lebih dari 3 bulan. PGK ditandai dengan satu atau lebih tanda kerusakan ginjal yaitu albuminuria, abnormalitas sedimen urin, elektrolit, histologi, struktur ginjal, ataupun adanya riwayat transplantasi ginjal, juga disertai penurunan laju filtrasi glomerulus. ${ }^{1}$

Saat ini banyak studi menunjukkan bahwa prevalensi PGK meningkat di berbagai wilayah di seluruh dunia. Prevalensi PGK derajat II sampai V terus meningkat sejak tahun 1988 sejalan dengan peningkatan prevalensi penyakit diabetes dan hipertensi yang juga merupakan penyebab PGK. ${ }^{2}$

Prevalensi gagal ginjal kronik (sekarang disebut PGK) di Indonesia pada pasien usia lima belas tahun keatas di Indonesia yang didata berdasarkan jumlah kasus yang didiagnosis dokter adalah sebesar $0,2 \%$. Prevalensi gagal ginjal kronik meningkat seiring bertambahnya usia, didapatkan meningkat tajam pada kelompok umur 25-44 tahun (0,3\%), diikuti umur 45-54 tahun $(0,4 \%)$, umur $55-74$ tahun $(0,5 \%)$, dan tertinggi pada kelompok umur $\geq 75$ tahun $(0,6 \%)$. Prevalensi pada laki-laki $(0,3 \%)$ lebih tinggi dari perempuan $(0,2 \%)^{3}$

Prevalensi PGK di Sumatera Barat sebesar $0,2 \%$. Prevalensi PGK tertinggi sebanyak $0,4 \%$ yaitu di Kabupaten Tanah Datar dan Kota Solok. Di Kota Padang didapatkan prevalensi PGK sebesar 0,3\%. Kejadian tertinggi PGK di Sumatera Barat adalah pada kelompok umur 45-54 tahun sebanyak 0,6\%. Perbandingan PGK berdasarkan jenis kelamin pria dan wanita adalah tiga berbanding dua. ${ }^{4}$

Penyebab kerusakan ginjal pada PGK adalah multifaktorial dan kerusakannya bersifat ireversibel. ${ }^{5}$ Penyebab PGK pada pasien hemodialisis baru di Indonesia adalah glomerulopati primer $14 \%$, nefropati diabetika $27 \%$, nefropati lupus/SLE $1 \%$, penyakit ginjal hipertensi $34 \%$, ginjal polikistik $1 \%$, nefropati asam urat $2 \%$, nefropati obstruksi $8 \%$, pielonefritis kronik/PNC $6 \%$, lain-lain $6 \%$, dan tidak diketahui sebesar $1 \%$. Penyebab terbanyak adalah penyakit ginjal hipertensi dengan persentase $34 \% .{ }^{6}$
Mekanisme dasar terjadinya PGK adalah adanya cedera jaringan. Cedera sebagian jaringan ginjal tersebut menyebabkan pengurangan massa ginjal, yang kemudian mengakibatkan terjadinya proses adaptasi berupa hipertrofi pada jaringan ginjal normal yang masih tersisa dan hiperfiltrasi. Namun proses adaptasi tersebut hanya berlangsung sementara, kemudian akan berubah menjadi suatu proses maladaptasi berupa sklerosis nefron yang masih tersisa. Pada stadium dini PGK, terjadi kehilangan daya cadang ginjal, pada keadaan dimana basal laju filtrasi glomerulus (LFG) masih normal atau malah meningkat. Secara perlahan tapi pasti akan terjadi penurunan fungsi nefron yang progresif. $^{7}$

Pada sepertiga penderita PGK mengeluhkan gejala berupa kekurangan energi (76\%), pruritus (74\%), mengantuk (65\%), dyspnea (61\%), edema $(58 \%)$, nyeri $(53 \%)$, mulut kering $(50 \%)$, kram otot $(50 \%)$, kurang nafsu makan $(47 \%)$, konsentrasi yang buruk (44\%), kulit kering (42\%), gangguan tidur (41\%), dan sembelit (35\%). ${ }^{8}$

Pasien PGK dengan ureum darah kurang dari $150 \mathrm{mg} / \mathrm{dl}$, biasanya tanpa keluhan maupun gejala. Gambaran klinis akan terlihat nyata bila ureum darah lebih dari 200 mg/dl karena konsentrasi ureum darah merupakan indikator adanya retensi sisa-sisa metabolisme protein di dalam tubuh. ${ }^{9}$ Uremia menyebabkan gangguan fungsi hampir semua sistem organ, seperti gangguan cairan dan elektrolit, metabolik-endokrin, neuromuskular, kardiovaskular dan paru, kulit, gastrointestinal, hematologi serta imunologi. $^{10}$

Modifikasi faktor resiko PGK dilakukan pada hipertensi, obesitas morbid, sindroma metabolik, hiperkolesterolemia, anemia, dan rokok. $^{2}$ Menurut KDIGO, PGK dengan tanda-tanda kegagalan ginjal (serositis, gangguan keseimbangan asam-basa atau elektrolit, pruritus), kegagalan pengontrolan volume dan tekanan darah, gangguan status gizi yang refrakter, dan gangguan kognitif membutuhkan terapi hemodialisis. Pada penderita yang sudah mencapai PGK derajat IV (eGFR $<30 \mathrm{~mL} /$ menit $/ 1,73 \mathrm{~m}^{2}$ ) juga harus dimulai terapi hemodialisis. ${ }^{1}$ 
Hemodialisis adalah proses pertukaran zat terlarut dan produk sisa tubuh. Zat sisa yang menumpuk pada pasien PGK ditarik dengan mekanisme difusi pasif membran semipermeabel. Perpindahan produk sisa metabolik berlangsung mengikuti penurunan gradien konsentrasi dari sirkulasi ke dalam dialisat. Dengan metode tersebut diharapkan pengeluaran albumin yang terjadi pada pasien PGK dapat diturunkan, gejala uremia berkurang, sehingga gambaran klinis pasien juga dapat membaik. ${ }^{1,11}$ Hemodialisis dapat mempengaruhi gambaran klinis penderita PGK, berupa gejala mual muntah, anoreksia, anemia, pruritus, pigmentasi, kelainan psikis, insomnia, hipertensi, maupun gejala lainnya. ${ }^{9}$

Data mengenai gambaran klinis penderita PGK yang menjalani hemodialisis di Indonesia khususnya di Sumatera Barat belum banyak tersedia, kebanyakan disampaikan adalah data mengenai gambaran klinis penderita PGK yang belum menjalani hemodialisis. Hal ini membuat peneliti tertarik untuk melakukan penelitian mengenai gambaran klinis pada penderita PGK (PGK derajat V) setelah menjalani hemodialisis di RSUP. Dr. M. Djamil Padang.

\section{METODE}

Penelitian ini merupakan studi deskriptif observasional yang telah dilakukan di bagian rekam medik dan unit hemodialisis RSUP Dr. M. Djamil Padang pada Agustus sampai November 2016. Sampel penelitian ini mencakup semua penderita PGK dewasa yang menjalani Hemodialisis (HD) dengan data rekam medis lengkap berupa umur dan jenis kelamin, data gambaran klinis dan hasil laboratorium. Pengambilan sampel dilakukan dengan mengambil seluruh sampel yang sesuai kriteria inklusi, yaitu sebanyak 104 sampel.

\section{HASIL}

Penelitian yang telah dilakukan di bagian rekam medik RSUP Dr. M. Djamil Padang mendapatkan jumlah pasien PGK yang menjalani hemodialisis pada tahun 2015 sebanyak 232 orang dengan rekam medik yang memenuhi kriteria sampel sebanyak 104 rekam medik.
Tabel 1. Karakteristik dasar penderita PGK yang menjalani hemodialisis di RSUP Dr. M. Djamil Padang

\begin{tabular}{lcc}
\hline \multicolumn{1}{c}{ Karakteristik } & f & $\%$ \\
\hline Usia & 23 & 22,1 \\
$\quad<40$ tahun & 65 & 62,5 \\
40-60 tahun & 16 & 15,4 \\
$\quad>60$ tahun & & \\
Jenis Kelamin & 59 & 56,7 \\
$\quad$ Laki-laki & 45 & 43,3 \\
$\quad$ Perempuan & & \\
Lama Hemodialisis & & \\
$<$ < bulan & 85 & 81,7 \\
3 bulan - 1 tahun & 19 & 18,3 \\
\hline
\end{tabular}

Berdasarkan data di atas, penderita PGK yang menjalani hemodialisis di RSUP Dr. M. Djamil Padang dari 1 Januari 2015 - 12 Desember 2015 terbanyak pada kelompok umur $40-60$ tahun $(62,5 \%)$. Pasien dengan jenis kelamin laki-laki memiliki presentasi lebih tinggi, yaitu sebanyak 56,7\%. Berdasarkan lama hemodialisis lebih banyak ditemukan pasien yang menjalani HD selama kurang dari 3 bulan $(81,7 \%)$.

Tabel 2. Gambaran klinis penderita PGK yang menjalani hemodialisis di RSUP Dr. M. Djamil Padang berdasarkan keluhan umum

\begin{tabular}{lcc}
\hline \multicolumn{1}{c}{ Keluhan Umum } & f & $\%$ \\
\hline Gangguan hematologi & 32 & 30,8 \\
Anemia (lelah, lemah, lesu) & & \\
Gangguan gastrointestinal dan nutrisi & & \\
Mual & 13 & 12,5 \\
Muntah & 8 & 7,7 \\
Berkurangnya nafsu makan & 14 & 13,5 \\
& & \\
Gangguan psikiatri & 12 & 11,5 \\
Insomnia & & \\
Kelainan kulit & 1 & 1 \\
Gatal & & \\
\hline
\end{tabular}

Berdasarkan data yang tertera di tabel atas, gambaran penderita PGK yang menjalani hemodialisis dilihat dari berbagai keluhan umum. Keluhan yang paling banyak $(30,8 \%)$ disampaikan pasien berupa lemah, letih, dan lesu. 
Tabel 3. Gambaran klinis penderita PGK yang menjalani hemodialisis di RSUP Dr. M. Djamil Padang berdasarkan hasil pemeriksaan fisik

\begin{tabular}{|c|c|c|}
\hline Hasil Pemeriksaan Fisik & $\mathbf{n}$ & $\%$ \\
\hline \multicolumn{3}{|l|}{ Gangguan keseimbangan cairan } \\
\hline Edema perifer & 56 & 53,8 \\
\hline Efusi pleura & 4 & 3,8 \\
\hline Asites & 5 & 4,8 \\
\hline \multicolumn{3}{|l|}{ Tekanan darah } \\
\hline Normal & 7 & 6,7 \\
\hline Prehipertensi & 31 & 29,8 \\
\hline Hipertensi Stage 1 & 34 & 32,7 \\
\hline Hipertensi Stage 2 & 32 & 30,8 \\
\hline \multicolumn{3}{|l|}{ Gangguan elektrolit \& asam basa } \\
\hline Asidosis metabolik & 10 & 9,6 \\
\hline \multicolumn{3}{|l|}{ Keadaan gizi } \\
\hline Baik & 5 & 4,8 \\
\hline Sedang & 98 & 94,2 \\
\hline Kurang & 1 & 1 \\
\hline \multicolumn{3}{|l|}{ Kelainan kulit } \\
\hline Kulit kering & 3 & 2,9 \\
\hline \multicolumn{3}{|l|}{ Gangguan neuromuskular } \\
\hline Kelemahan otot & 1 & 1 \\
\hline Ensefalopati uremikum & 7 & 6,7 \\
\hline \multicolumn{3}{|l|}{ Gangguan hematologi } \\
\hline anemia (konjungtiva anemis) & 65 & 62,5 \\
\hline \multicolumn{3}{|l|}{ Gangguan sistem urinarius } \\
\hline Oliguria & 17 & 16,3 \\
\hline
\end{tabular}

Berdasarkan Tabel 3, gambaran hasil pemeriksaan fisik pada penderita PGK yang menjalani HD juga beragam. Pada pemeriksaan fisik ditemukan penderita mengalami edema perifer sebanyak $53,8 \%$, hipertensi stage 1 sebanyak 32,7\%, dan konjungtiva yang anemis sebanyak $62,5 \%$ penderita. Keadaan gizi penderita didapatkan $94,2 \%$ sedang.

Tabel 4. Gambaran klinis penderita PGK yang menjalani hemodialisis di RSUP Dr. M. Djamil Padang berdasarkan hasil pemeriksaan hemoglobin

\begin{tabular}{ccc}
\hline $\begin{array}{c}\text { Hasil Pemeriksaan } \\
\text { Hemoglobin (g/dl) }\end{array}$ & f & $\%$ \\
\hline$<7$ & 7 & 6,7 \\
$7-10$ & 71 & 68,3 \\
$>10$ & 26 & 25 \\
\hline
\end{tabular}

Berdasarkan hasil pemeriksaan laboratorium seperti pada Tabel 4 pada penderita PGK yang menjalani HD didapatkan kadar hemoglobin penderita terbanyak (68,3\%) dengan $\mathrm{Hb}$ 7-10 g/dl.

\section{PEMBAHASAN}

Berdasarkan penelitian yang telah dilakukan di RSUP Dr. M. Djamil Padang, didapatkan sebanyak 104 rekam medik penderita PGK yang menjalani HD selama tahun 2015 yang memenuhi kriteria sampel. Dalam penelitian ini penderita penyakit ginjal kronik yang menjalani HD di RSUP Dr. M. Djamil Padang berdasarkan usia didapatkan kelompok usia terbanyak adalah 40-60 tahun sebanyak 65 pasien (62,5\%), diikuti kelompok usia <40 tahun sebanyak 23 pasien $(22,1 \%)$, dan $>60$ tahun sebanyak 16 pasien $(15,4 \%)$. Penurunan fungsi ginjal merupakan proses normal setiap bertambahnya usia manusia. Bertambahnya usia menunjukkan penurunan progresif Glomerular Filtrasion Rate (GFR) dan Renal Blood Flow (RBF). Penurunan terjadi sekitar $8 \mathrm{ml} /$ menit $/ 1,73 \mathrm{~m}^{2}$ setiap dekadenya sejak usia 40 tahun. $^{12}$

Jenis kelamin terbanyak adalah pria dengan jumlah 59 pasien $(56,7 \%)$, sedangkan jenis kelamin wanita berjumlah 45 pasien (43,3\%). Hasil tersebut kemungkinan berkaitan dengan kejadian penyakit penyebab PGK, seperti batu ginjal, yang juga banyak terjadi pada jenis kelamin pria. Penelitian lain mendapatkan prevalensi penyakit batu ginjal pada laki-laki dan wanita adalah $10,6 \%$ dan $7,1 \%{ }^{13}$

Pasien yang menjalani HD kurang dari 3 bulan sebanyak 85 pasien $(81,7 \%)$. Pasien yang menjalani HD selama 3 bulan hingga 1 tahun sebanyak 19 pasien $(18,3 \%)$. Ditemukan lebih banyak pasien yang menjalani HD kurang dari 3 bulan, kemungkinan karena penelitian ini dilakukan hanya pada 1 tahun yaitu tahun 2015, sehingga pasien yang didapatkan kebanyakan merupakan pasien yang baru memulai HD. Pasien yang sudah menjalani HD sejak 2015 dan masih melakukan HD pada tahun 2015 tidak dapat dilakukan pengamatan karena pasien-pasien tersebut merupakan pasien rawat jalan yang tidak ada data pemeriksaan fisik umum lengkapnya di rekam medik. Penelitian lain mendapatkan 34\% pasien menjalani HD selama 3 bulan hingga 1 tahun dan $66 \%$ pasien menjalani HD selama lebih dari 1 tahun. ${ }^{14}$

Berdasarkan hasil penelitian diketahui bahwa 17 pasien $(16,3 \%)$ mengeluhkan oliguria. Sebanyak 87 pasien $(83,7 \%)$ tidak mengeluhkan oliguria. Oliguria terjadi karena terganggunya fungsi ginjal untuk mempertahankan homeostasis cairan tubuh dengan 
kontrol volume cairan, sehingga cairan menumpuk di dalam tubuh. Pada penelitian ini, didapatkan banyak pasien yang tidak mengeluhkan oliguria. Kemungkinan ini dikarenakan pada penelitian ini kebanyakan pasien masih baru dalam menjalani hemodialisis sehingga dapat dikatakan kerusakan fungsi ginjalnya belum terlalu parah, sehingga gejala oliguria (penurunan urine output) belum begitu terlihat. Efek medikasi yang dilakukan terhadap kelebihan cairan juga bisa mempengaruhi urine output, seperti pemberian diuretik, yang dapat meningkatkan urine output. Penelitian lain mendapatkan bahwa kejadian anuria meningkat sejalan dengan lamanya menjalani hemodialisis (52\% pada pasien yang HD selama 4 bulan dan $67 \%$ pada pasien yang HD selama 12 bulan) dikarenakan walaupun semakin lama seorang pasien menjalani HD progresifitas PGKnya tetap akan berlangsung, sehingga fungsi ginjal tetap akan semakin menurun dan urine output semakin berkurang. ${ }^{15}$

Gambaran kelebihan cairan yang terjadi pada pasien didapatkan asites pada 5 pasien (4,8\%), sedangkan 99 orang pasien (95,2\%) tidak ditemukan asites. Pada 4 orang pasien (3,8\%) ditemukan adanya efusi pleura, 96,2\% pasien tidak ditemukan efusi pleura. Sebanyak 56 pasien $(53,8 \%)$ mengalami edema perifer dan 48 orang sisanya $(46,2 \%)$ tidak mengalami edema perifer.

Kelebihan cairan pada pasien PGK disebabkan karena terganggunya fungsi ginjal untuk menjalankan fungsi ekskresinya. Gambaran kejadian kelebihan cairan seperti asites dan efusi pleura menunjukkan jumlah yang sedikit, dapat disebabkan oleh terapi hemodialisis. Pada mesin dialisis dilakukan penarikan cairan sampai tercapai berat badan kering, yaitu berat badan dimana sudah tidak ada cairan berlebihan dalam tubuh. Kelebihan cairan tubuh dialirkan ke dalam mesin dialyzer yang alirannya dikontrol oleh pompa. Lalu cairan tersebut akan dikeluarkan dari sirkulasi sistemik secara simultan selama HD. ${ }^{16}$

Penelitian lain mendapatkan insiden efusi pleura pada pasien yang menerima hemodialisis jangka panjang adalah sebesar 20,2\%. Pada penelitian tersebut 14 dari 52 pasien yang efusi pleura menjalani torakosentesis, didapatkan 64,3\% mengalami efusi pleura tipe transudat dan $35,7 \%$ tipe eksudat. Penyebab efusi tipe transudat adalah hipervolemia $(66,7 \%)$ dan gagal jantung (22,2\%). Efusi eksudat paling banyak disebabkan oleh pleuritis (40\%). Perbedaan ini kemungkinan karena pasien pada penelitian Bakirci et al telah menjalani hemodialisis dalam jangka panjang sehingga progresifitas PGKnya lebih tinggi, dimana sudah menimbulkan berbagai komplikasi seperti gagal jantung dan infeksi. ${ }^{17}$

Penelitian lain mendapatkan rata-rata pasien yang mengeluhkan pembengkakan pada kaki adalah sebanyak 32\%, hasil ini juga menunjukkan angka sedikit besar seperti pada penelitian penulis. ${ }^{18}$ Edema perifer pada pasien merupakan akibat dari penumpukan cairan karena berkurangnya tekanan osmotik plasma dan retensi natrium dan air. Akibat peranan dari gravitasi, cairan yang berlebih tersebut akan lebih mudah menumpuk di tubuh bagian perifer seperti kaki, sehingga edema perifer akan lebih cepat terjadi dibanding gejala kelebihan cairan lainnya. Karena hal tersebut kejadian edema perifer pada pasien cukup tinggi.

Gambaran tekanan darah pada pasien didapatkan 7 pasien $(6,7 \%)$ dengan tekanan darah normal, 31 pasien $(29,8 \%)$ dengan prehipertensi, 34 pasien $(32,7 \%)$ dengan hipertensi stage 1 , dan 32 pasien $(30,8 \%)$ dengan hipertensi stage 2. Hampir $30 \%$ PGK disebabkan oleh hipertensi dan prevalensi hipertensi pada pasien baru PGK adalah lebih dari $85 \%$. Ditemukannya pasien dengan tekanan darah normal dan prehipertensi pada penelitian ini juga dapat disebabkan karena pasien yang mengalami penyakit ginjal tahap akhir umumnya mendapatkan regimen antihipertensi untuk mengendalikan tekanan darahnya. $^{19}$

Berdasarkan penelitian didapatkan 10 pasien $(9,6 \%)$ mengalami asidosis metabolik sedangkan 94 pasien $(90,4 \%)$ tidak mengalaminya. Asidosis metabolik relatif umum terjadi pada pasien PGK, khususnya ketika LFG turun di bawah $30 \mathrm{ml} / \mathrm{menit}$ dan dapat mempengaruhi sekitar $30-50 \%$ pasien. Hilangnya fungsi ginjal secara progresif menyebabkan berkurangnya kemampuan tubulus untuk memanfaatkan amonia dalam mengekskresikan sekitar $1 \mathrm{mmol} / \mathrm{kgBB}$ hidrogen yang diproduksi setiap hari pada keadaan fisiologis. ${ }^{20}$ 
Gambaran gangguan sistem gastrointestinal pada penderita PGK yang menjalani HD dilihat dari keluhan mual, muntah, dan tidak nafsu makan. Hasil penelitian menunjukkan sebanyak $12,5 \%$ pasien mengeluhkan mual, sedangkan sisanya tidak mual. Sebanyak 8 pasien $(7,7 \%)$ mengalami muntah, sementara 96 pasien $(92,3 \%)$ tidak mengalami muntah. Sebanyak 14 pasien (13,5\%) tidak nafsu makan (anoreksia) dan 90 pasien $(86,5 \%)$ tidak mengeluhkan anoreksia.

Mual dan muntah yang ditemukan pada pasien PGK diduga karena gastroparesis atau keterlambatan pengosongan lambung. ${ }^{21}$

Anoreksia yang terjadi pada pasien PGK diperkirakan akibat efek ureum yang menumpuk. Berdasarkan gambaran kejadian anoreksia pada pasien didapatkan sebagian besar pasien tidak mengalami anoreksia. Hal tersebut sesuai dengan penelitian lain yang mendapatkan bahwa semakin lama hemodialisis dijalani maka semakin tinggi kejadian anoreksianya. ${ }^{22}$ Pada penelitian ini, sebagian besar sampel merupakan pasien yang menjalani hemodialisis belum cukup lama yaitu selama kurang dari tiga bulan.

Keadaan gizi pasien berdasarkan hasil pemeriksaan dokter terbanyak adalah gizi sedang, yaitu 98 orang (94,2\%). Sisanya 5 pasien $(4,8 \%)$ dengan status gizi baik dan 1 pasien (1\%) dengan status gizi buruk.

Penurunan keadaan gizi pada pasien PGK dapat diakibatkan oleh rendahnya asupan makanan. Rendahnya asupan makanan tersebut dapat disebabkan oleh gangguan gastrointestinal seperti yang dijelaskan diatas, yaitu anoreksia dan mual serta muntah. Hasil penelitian lain yang sejalan menunjukkan bahwa Indeks Massa Tubuh pasien PGK yang menjalani hemodialisis yang adekuat, sebagian besar $(81,25 \%)$ adalah normal. ${ }^{23}$

Lebih dari $90 \%$ didapatkan pasien dengan keadaan gizi sedang mungkin dikarenakan pengukuran status gizi yang dilakukan menggunakan Indeks Massa Tubuh (IMT). IMT diperoleh berdasarkan hasil pengukuran berat badan dan tinggi badan pasien saat hemodialisis. Sementara pada pasien PGK diketahui terjadi penumpukan cairan tubuh akibat berkurangnya fungsi ekskresi ginjal, sehingga berat badan yang diukur saat itu tidaklah menggambarkan status gizi pasien yang sebenarnya.

Satu orang pasien (1\%) mengeluhkan gatal. Sebanyak 103 pasien (99\%) tidak mengeluhkannya. Sedikitnya jumlah pasien yang mengeluhkan gatal (pruritus) mungkin dikarenakan gatal bukan menjadi fokus utama dari hal yang dianggap mengganggu oleh pasien seperti mual, muntah, dan keluhan lainnya. Penelitian lain mendapatkan $42 \%$ pasien yang menjalani HD mengalami pruritus sedang-berat. Pruritus sedikit lebih jarang terjadi pada pasien yang baru memulai dialisis dibanding pasien yang telah menjalani hemodialisis lebih dari 3 bulan, namun kejadian ini diperkirakan bukan dikarenakan pengaruh dari HD dan penyebabnya masih belum diketahui. ${ }^{24}$

Pada 3 orang pasien (2,9\%) didapatkan kulit yang kering, dan sisanya sebanyak 101 pasien $(97,1 \%)$ tidak didapatkan kulit yang kering. Kejadian kulit yang tampak kering pada pasien PGK disebabkan karena adanya penumpukan urea (urea frost). Menjadi berkurang pada pasien yang hemodialisis kemungkinan dikarenakan terapi hemodialisis yang dilakukan. Ureum yang bertumpuk karena terganggunya fungsi ginjal akan dikurangi jumlahnya oleh mesin dialisat. Penelitian lain yang berhubungan mendapatkan $65 \%$ pasien mengeluhkan kulit kering. Pada hasil penelitian tersebut juga disebutkan bahwa berdasarkan laporan dari tenaga kesehatan yang memeriksa pasien PGK, hanya $11 \%$ yang menyatakan ditemukan kulit yang kering pada pasien dan $36 \%$ menyatakan tidak tahu. ${ }^{18}$ Kurangnya perhatian tenaga medis terhadap pemeriksaan kondisi kulit pada pasien mungkin menjadi sebab sedikitnya angka kejadian kulit yang kering pada penderita PGK.

Berdasarkan penelitian didapatkan 1 pasien (1\%) mengalami kelemahan otot, sementara sisanya (99\%) tidak didapatkan kelemahan. Hal ini kemungkinan karena pasien yang ada di penelitian ini sebagian besar menjalani HD selama kurang dari 3 bulan, berarti derajat kerusakan ginjalnya masih belum separah pasien yang telah lama menjalankan HD yang progresifitas penyakitnya tentu lebih besar, sehingga kelemahan otot belum begitu terlihat pada sebagian besar pasien di penelitian ini. Ditemukannya 1 orang pasien yang mengalami kelemahan kemungkinan karena penyakitnya yang sudah berat, pasien tersebut 
juga sudah mengalami komplikasi ensefalopati uremikum, sementara pasien ini baru menjalani HD selama 1 bulan, keterlambatan pengobatan mungkin dapat menyebabkan kelemahan pada pasien tersebut.

Komplikasi neurologis sering mempengaruhi pasien PGK berupa gangguan pada pusat ataupun perifer dan jarang terdiagnosis maupun terobati. Ensefalopati uremikum merupakan salahsatu manifestasi klinis akibat uremia yang paling berat. Terapi dialisis dapat memperbaiki tampilan klinis dan perkembangan komplikasi neurologis pada pasien, tetapi mungkin juga secara langsung dapat menginduksi kelainan terkait dialisis. ${ }^{25}$ Berdasarkan pengamatan yang dilakukan terhadap komplikasi neurologis yang terjadi pada pasien yang menjalani HD, didapatkan 7 pasien $(6,7 \%)$ mengalami ensefalopati uremikum dan 97 pasien (93,3\%) tidak mengalaminya.

Berdasarkan penelitian didapatkan bahwa 12 penderita PGK yang menjalani HD (11,5\%) mengeluhkan insomnia, sedangkan 92 pasien lainnya $(88,5 \%)$ tidak mengeluhkan hal tersebut. Hasil penelitian ini berbeda dengan penelitian lain pada pasien yang menjalani hemodialisis lebih dari 6 bulan mendapatkan $46 \%$ pasien mengalami insomnia, dimana mekanismenya adalah peningkatan osteodistrofi ginjal pada hemodialisis jangka lama yang menyebabkan nyeri pada anggota gerak, sehingga mengganggu tidur pasien pada malam hari. ${ }^{26}$ Perbedaan tersebut tersebut mungkin karena pada penelitian ini semua sampel menjalani hemodialisis kurang dari 12 bulan.

Gambaran kejadian anemia pada penderita PGK, ditunjukkan dengan keluhan berupa lemah, letih, lesu, temuan pemeriksaan fisik berupa konjungtiva anemis, dan temuan laboratorium berupa penurunan hemoglobin. Pada penelitian ini, didapatkan sebanyak 32 pasien $(30,8 \%)$ mengeluhkan lemah, letih, dan lesu, sedangkan sisanya sebanyak 72 orang $(69,2 \%)$ tidak mengeluhkannya. Sebanyak 65 pasien $(62,5 \%)$ ditemukan konjungtiva yang anemis pada pemeriksaan fisiknya, sedangkan sisanya tidak. Data hasil pemeriksaan laboratorium menunjukkan sebanyak 7 pasien $(6,7 \%)$ memiliki kadar hemoglobin (Hb) kurang dari $7 \mathrm{~g} / \mathrm{dl}$, sebanyak 71 pasien $(68,3 \%)$ memiliki Hb 7-10 g/dl, dan 26 orang (25\%) memiliki $\mathrm{Hb}$ $>10 \mathrm{~g} / \mathrm{dl}$.

Gambaran anemia yang ditunjukkan pada data tersebut cukup beragam, banyak pasien yang tidak mengeluhkan lemah, letih, dan lesu sementara pada pemeriksaan fisik masih banyak ditemukan konjungtiva pasien yang anemis. Pemeriksaan laboratorium menunjukkan kadar $\mathrm{Hb}$ terbanyak ialah pada 7-10 g/dl, dimana nilai tersebut masih dikatakan anemia pada pasien PGK. Hasil penelitian ini sejalan dengan penelitian lain yang mendapatkan kadar $\mathrm{Hb}$ rata-rata pada pasien PGK yang menjalani hemodialisis adalah $8,7 \mathrm{~g} / \mathrm{dll}^{27}$ Hasil ini menunjukkan bahwa pasien yang diindikasikan transfusi darah (kadar $\mathrm{Hb}<7$ g/dl pada pasien PGK) jumlahnya sedikit. Pada pasien yang menjalani hemodialisis, target hemoglobin yang normal $(7-8 \mathrm{~g} / \mathrm{dl})$ menurunkan kebutuhan transfusi darah. ${ }^{28}$

\section{SIMPULAN}

Ada lebih dari separuh penderita PGK yang menjalani hemodialisis di RSUP Dr. M. Djamil berusia 40 - 60 tahun dan berjenis kelamin laki-laki. Sebagian besar penderita menjalani hemodialisis selama $<3$ bulan.

Gambaran klinis penderita PGK yang menjalani hemodialisis di RSUP Dr. M. Djamil Padang yang terbanyak adalah keluhan lemah, letih, dan lesu, pemeriksaan fisik yang banyak ditemukan dengan edema perifer, konjungtiva yang anemis, keadaan gizi sedang, dan hipertensi derajat 1 , serta anemia pada pemeriksaan laboratorium.

\section{DAFTAR PUSTAKA}

1. KDIGO. Clinical practice guideline for the evaluation and management of chronic kidney disease. 2012 (diunduh Februari 2016). Tersedia dari: http://www.kdigo.org/clinical practice guide lines/pdf/CKD/KDIGO 2012 CKD GL.pdf

2. Henry Ford Health System. Chronic kidney disease: Clinical practice recommendations for primary care physcians and healthcare providers. Edition 6.0. 2011 (diunduh Februari 2016). Tersedia dari: https://www.asn-online.org/educati on/t raining/fellows/HFH S CKD V6.pdf 
3. Badan Penelitian dan Pengembangan Kesehatan Kementerian Kesehatan RI. Riset kesehatan dasar. Bakti Husada; 2013.

4. Badan Penelitian dan Pengembangan Kesehatan Kementerian Kesehatan RI. Riset kesehatan dasar dalam angka Provinsi Sumatera Barat. Bakti Husada; 2013.

5. SIGN. Diagnosis and management of chronic kidney disease: A national clinical guideline. 2008 (diunduh Februari 2016). Tersedia dari: http://www.sign.ac.uk/pdf/sign103.pdf

6. PERNEFRI. $4^{\text {th }}$ report of indonesian renal registry. 2011 (diunduh Februari 2016). Tersedia dari: http://www.indonesianrenalregistry.org/data/4th\% 20Annual\%20Report\%200f\%20IRR\%202011.pdf

7. Suwitra K. Penyakit ginjal kronik. Dalam: Setiati S, Alwi I, Sudoyo AW, Simadibrata M, Setiyohadi B, Syam AF (eds). Buku ajar ilmu penyakit dalam jilid 1. Edisi ke-6. Jakarta: Interna Publishing; 2014.

8. Murtagh FE, Addinationhall JM, Edmons PM, Donohoe P, Carey I, Jenkins K, Higginson IJ. Symptoms in advanced renal disease: A crosssectional survey of symptom prevalence in stage 5 chronic kidney disease managed without dialysis. Journal Of Palliative Medicine. 2007; 10 1266-76.

9. Sukandar E. Nefrologi klinik. Edisi ke-3. Bandung: Pusat Informasi IImiah bagian IImu Penyakit Dalam Fakultas Kedokteran UNPAD/RS. Dr Hasan Sadikin; 2006.

10. Bargman JM, Skorecki K. Chronic kidney disease. Dalam: Jameson JL, Loscalzo J, editor (penyunting). Harrison's nephrology and acidbase disorders. Edisi ke-1. New York: The MacGraw-Hill Companies; 2010.

11. Liu KD, Chertow GM. Dialysis in the treatment of renal failure. Dalam: Jameson JL, Loscalzo J, editor (penyunting). Harrison's nephrology and acid-base disorders. Edisi ke-1. New York: The MacGraw-Hill Companies; 2010.

12. Weinstein JR, Anderson S. The aging kidney: Physiological changes. Nih Public Access. 2010; 17(4):302-7.

13. Scales CD, Smith AC, Hanley JM, Saigal CS. Prevalence of kidney stones in United States. European Urology. 2012;62(1):160-5.
14. Salawati L. Analisis lama hemodialisis dengan status gizi penderita penyakit ginjal kronik. Jurnal Kedokteran Syiah Kuala. 2016;16(2):64-8.

15. Daugirdas JT, Greene T, Rocco MV, Kaysen GA, Depner TA, Levin NW, et al. Effect of frequent hemodialysis on residual kidney function. Kidney International. 2013;83:949-58.

16. Hsu TW, Chen YC, Wu MJ, Li AF, Yang WC, Ng YY. Reinfusion of ascites during hemodialysis as a treatment of massive refractory ascites and acute renal failure. International Journal Of Nephrology And Renovasclar Disease. 2011;4: 29-33.

17. Bakirci T, Sasak G, Ozturk S, Akcay S, Sezer S, Maberal M. Pleural effusion in long term hemodialysis patients. Transplantation Proceeding. 2007;39:889-91.

18. Weisbord SD, Fried LF, Mor MK, Resnick AL, Unruh ML, Palevsky PM. Renal provider recognition of symptoms in patients on maintenance hemodialysis. Clinical Journal Of The American Society Of Nephrology. 2007; 2: 960-7.

19. Supadmi W. Evaluasi penggunaan obat antihipertensi pada pasien gagal ginjal kronik yang menjalani hemodialisis. Jurnal IImiah Kefarmasian. 2011;1(1):67-80.

20. Ashurst IB, Olene E, Kaushik T, Mccaferty K, Yaqoob MM. Acidosis: Progression of chronic kidney disease and quality of life. Journal Of The International Pediatric Nephrology Association. 2014;30:873-9.

21. Pardede. Gangguan gastrointestinal pada penyakit ginjal kronis. CDK - 195. 2012;39(7): 501-7.

22. Santoso BR, Manatean $Y$, Asbullah. Hubungan lama hemodialisis dengan penurunan nafsu makan pada psieen gagal ginjal kronik di unit hemodialisa RSUD Ulin Banjarmasin. Dinamika Kesehatan. 2016;7:139-51.

23. Zuyana L, Meryana A. Perbedaan asupan makanan dan status gizi antara pasien hemodialisis adekuat dan inadekuat penyakit ginjal kronik. Media Gizi Indonesia. 2013;9:13-9

24. Pisoni RL, Wikstrom B, Elder SJ, Akizawa T, Asano Y, Keen ML, et al. Pruritus in 
haemodialysis patients: International results from the dialysis outcomes and practice patterns study (dopps). Oxford Journals. 2006;21:3495-505.

25. Rizzo MA, Frediani F, Granata A, Ravasi B, Cusi D, Gallieni M. Neurological complications of hemodialysis: State of the art. Journal Of Nephrology. 2012;25(02):170-82.

26. Malaki M, Mortazavi FS, Moazemi S, Shoaran M. Insomnia and limb pain in hemodialysis patiens: What is the share of share of restless leg syndrome. Saudi J Kidney Dis Transpl. 2012; 23(1):15-20

27. Suyatno FE, Rotty LWA, Moeis ES. Gambaran anemia defisiensi pada penyakit ginjal kronik stadium v yang menjalani hemodialisis di Instalasi tindakan hemodialisis rsup prof $d r \quad d$ kandou manado. Jurnal Eclinic. 2016;4(1):146-51.

28. Folley RN, Curtis BM, Parfrey PS. Erythropoietin therapy, hemoglobin targets, and quality of life in healthy hemodialysis patients: A randomized trial. Clin J Am Soc Nephrol. 2009;4:726-33. 